EUROPA REGIONUM TOM XXVIII ROK 2016

DOI: $10.18276 /$ er.2016.28-20

\author{
BART七OMIEJ PRZYBYŁa, BOGUSŁAW STANKIEWICZ \\ Zachodniopomorski Uniwersytet Technologiczny w Szczecinie
}

\title{
Ocena ruchu turystycznego w gminie Szczecin - bariery rozwoju
}

\section{Wprowadzenie}

7 e względu na posiadane liczne walory turystyczne Szczecin jest miastem, 4 które poprzez odpowiednie działania promocyjne władz samorządowych mogłoby osiągnąć duży sukces jako ośrodek turystyczny. Chociaż w Szczecinie odbyły się liczne imprezy turystyczne - na przykład zloty żaglowców The Tall Ship's Races 2007 i 2013 r. - skutkiem których jest wzrost liczby turystów odwiedzających miasto, wciąż jednak brakuje kompleksowej i długotrwałej kampanii promocyjnej, skutkiem której byłoby budowanie trwałej relacji z turystami. Kampanie turystyczne, stosowane przez inne ośrodki miejskie stanowią integralny element szeroko rozumianych wieloletnich planów strategicznych, w których przyrost liczby turystów uznaje się za czynnik trwale powiązany z rozwojem gospodarczym tych ośrodków. Poprzez stosowanie różnego rodzaju działań promocyjnych, adaptację i wdrażanie rozwiązań $\mathrm{z}$ innych miast w Szczecinie, władze samorządowe mogłyby przyczynić się do jeszcze lepszego wykorzystania zarówno potencjału turystycznego Szczecina, jak również czynników wynikających z szeroko rozumianego procesu integracji europejskiej, której jednym z przejawów jest funkcjonowanie instytucji Strefy Schengen, która pozwala na przekraczanie granic państw na terenie Unii Europejskiej oraz Szwajcarii i Norwegii bez konieczności odbywania kontroli granicznych. Szczecin, jako miasto przygraniczne, korzysta w sposób szczególny $\mathrm{z}$ ułatwień wynikających z liberalizacji przepisów dotyczących przemieszczania się osób na terenie Europy, co w połączeniu z wysokim kursem euro do złotego pozwala 
lokalnym przedsiębiorcom z branży turystycznej i gastronomicznej na osiąganie dużych zysków przy oferowaniu obcokrajowcom stosunkowo niskich cen.

Mimo korzystnych zmian w strukturze ruchu turystycznego w Szczecinie, gmina wciąż nie osiąga $\mathrm{z}$ tego tytułu przychodów na tyle wysokich, aby można było uznać miasto za prężnie rozwijający się ośrodek turystyczny, gdzie roczna liczba udzielanych noclegów przewyższa kilkakrotnie liczbę mieszkańców, a wpływy z podatków od różnych form działalności turystycznej stanowią wyraźny odsetek dochodów gminy.

\section{Wolumen ruchu turystycznego w Szczecinie w latach 2009-2014}

Badanie całości wolumenu ruchu turystycznego zawsze jest obarczone dużym niedoprecyzowaniem wynikającym $\mathrm{z}$ faktu, iż oficjalne dane urzędowe uwzględniają tylko tych turystów, którzy wykupili przynajmniej jeden nocleg w placówce świadczącej usługi hotelowe, pomijając gości jednodniowych oraz osoby, które zatrzymały się u rodziny lub znajomych. W przypadku Szczecina, owe niedoprecyzowanie jest zazwyczaj jeszcze większe, położenie geograficzne miasta bowiem sprzyja odbywaniu podróży jednodniowych relatywnie częściej niż w przypadku innych miast. Liczba turystów odwiedzających miasta zależy zarówno od czynników lokalnych, jak na przykład kampanie promocyjne prowadzone przez samorządy, jak również międzynarodowych, do jakich należą na przykład kursy walut rozstrzygające o kierunku podróży wśród turystów zagranicznych.

Wolumen ruchu turystycznego w Szczecinie w ostatnich latach systematycznie rósł i był to wzrost zasadniczo stały - wyjątkiem był rok 2012, gdy liczba turystów korzystających z noclegów ogółem w Szczecinie spadła względem roku poprzedniego z 376021 do 371 712, co mogło być spowodowane odbywającymi się w tym roku mistrzostwami Europy w piłce nożnej, które przyczyniły się do zmiany kierunków wybieranych przez turystów odwiedzających Polskę. Wolumen ruchu turystycznego w Szczecinie szacowanego według wskaźnika liczby turystów korzystających z noclegów ogółem, wzrósł w latach 2009-2014 ze 354234 do 388082 osób, co oznacza przyrost o prawie $10 \%{ }^{1}$.

Rysunek 1 prezentuje liczbę turystów korzystających z noclegów ogółem w Szczecinie w latach 2009-2014.

\footnotetext{
${ }^{1}$ Główny Urząd Statystyczny, 2015.
} 
B. Przybyła, B. Stankiewicz: Ocena ruchu turystycznego w gminie Szczecin ... 281

Turyści korzystający z noclegów ogółem

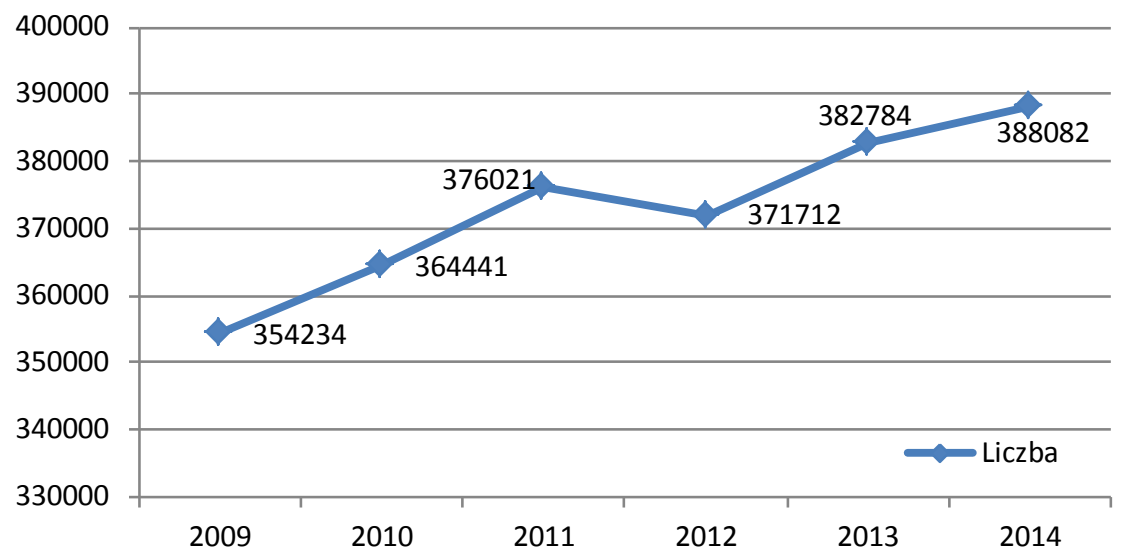

Rysunek 1. Turyści korzystający z noclegów ogółem w Szczecinie w latach 2009-2014 Źródło: GUS.

Dwa ujęcia rysunku 2, prezentuje liczbę turystów zagranicznych korzystających z noclegów ogółem w Szczecinie w latach 2009-2014.

Turyści zagraniczni korzystający z noclegów

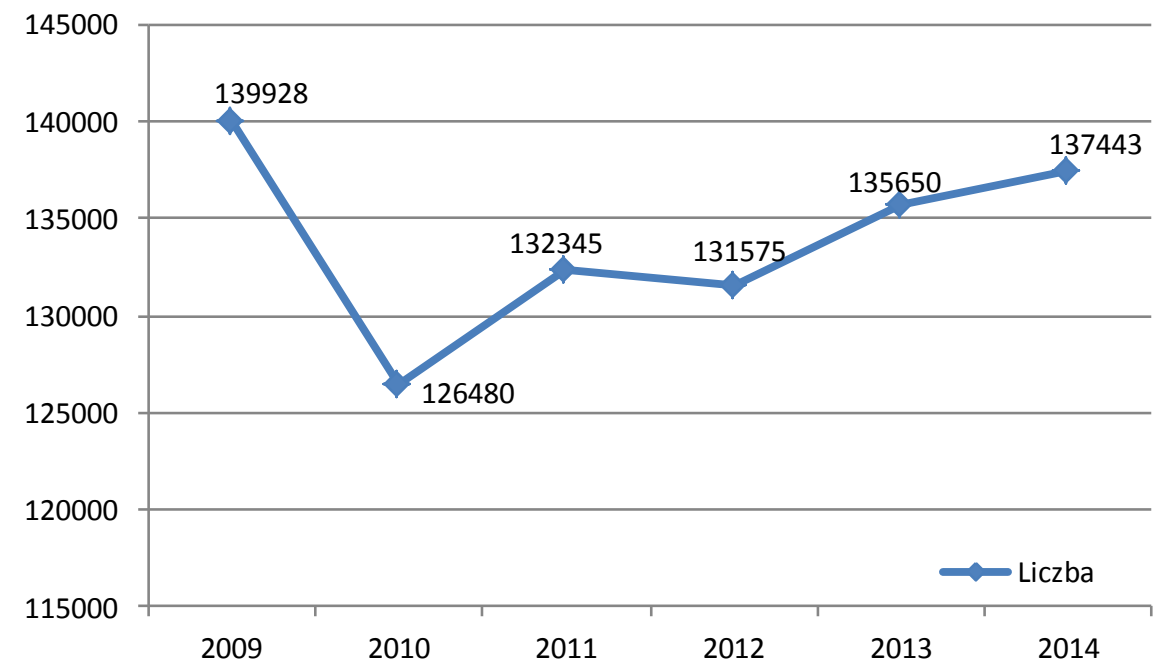

Rysunek 2. Turyści zagraniczni korzystający z noclegów ogółem w Szczecinie w latach 2009-2014

Źródło: GUS. 
Porównując wykres $1 \mathrm{z}$ wykresem 2 można łatwo zauważyć, że przyrost liczby turystów ogółem charakteryzuje się znacznie większą stałością niż turystów zagranicznych. Oznacza to, że wśród turystów polskich należy odnotować niewielki, aczkolwiek systematyczny przyrost.

Omawiając zagadnienia związane $\mathrm{z}$ ruchem turystycznym oraz polityką marketingową Gminy Szczecin należy odnieść mierniki ruchu turystycznego do wydatków gminy ponoszonych na działalność promocyjną. Należy zauważyć fakt, że dodatnia korelacja uwidoczniona jest z pewnym opóźnieniem, które wynosi około 2 lat. Przybliżone wydatki Gminy Miasto Szczecin na promocję turystyczną w poszczególnych latach w milionach złotych wyniosły 6 - w 2009 r., 4,1 - 2010 i 2011 r., 5,75 - 2012 r., 4,2 - 2013 r., 4 - 2014 r. Przy przeprowadzaniu badania korelacji przy użyciu współczynnika Pearsona, słabą dodatnią korelację $(0,31391872)$ odnotowano przy odnoszeniu liczby turystów korzystających z noclegów ogółem do wydatków promocyjnych gminy poniesionych 2 lata wcześniej².

Rysunek 3 przedstawia wydatki budżetowe Gminy Miasto Szczecin na promocję w latach 2009-2014.

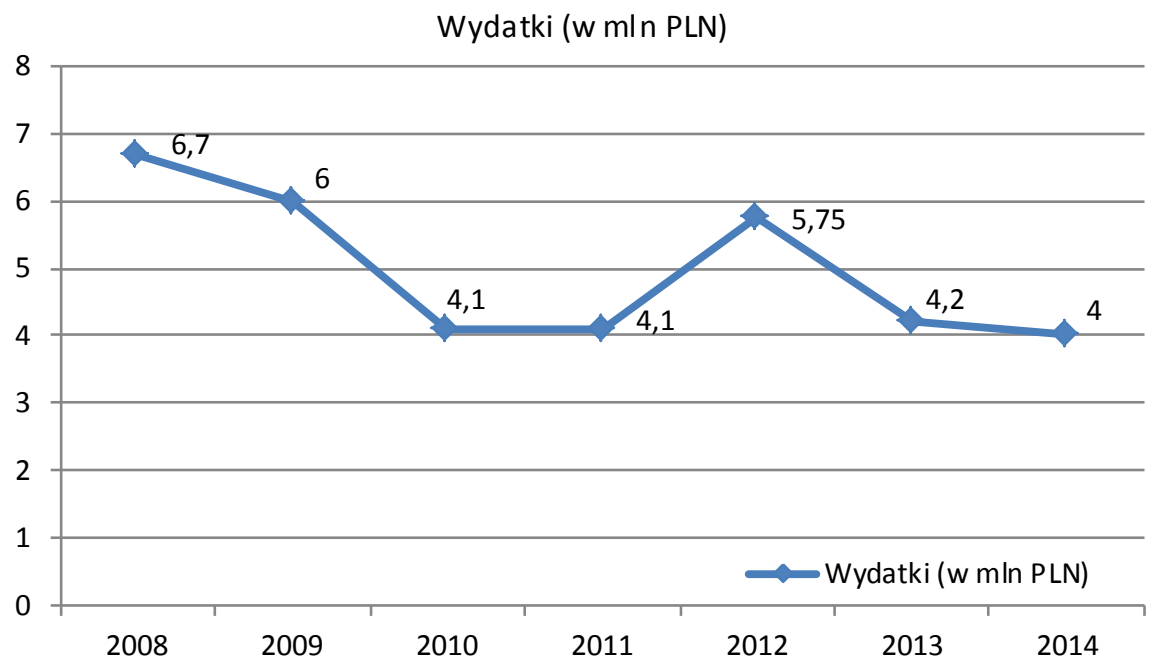

Rysunek 3. Wydatki Gminy Miasto Szczecin na promocję w latach 2009-2014 Źródło: UM Szczecin.

\footnotetext{
${ }^{2}$ Główny Urząd Staty sty czny, 2015 r.
} 
Próbę oszacowania liczby turystów, którzy odwiedzili Szczecin na jeden dzień - a ściślej ich udziału w całości wolumenu ruchu turystycznego w Szczecinie - można podjąć w oparciu o strukturę dystrybucji biletów dobowych i wielodobowych komunikacji miejskiej. Jest to jednak nadal narzędzie mało precyzyjne, gdyż pomija ono turystów, którzy przyjechali do Szczecina i poruszają się po mieście przy użyciu własnych samochodów, jak również tych, którzy korzystają z biletów jednorazowych. Odsetek dystrybucji biletów jednodobowych w strukturze dystrybucji biletów jedno- i wielodobowych ogółem systematycznie spada - od 96,30\% w 2009 roku do 93,41\% - co może wskazywać na wzrost udziału liczby turystów odwiedzających Szczecin na dłużej niż jeden dzień; są to jednak wskaźniki poglądowe, na podstawie których można określić trend, bez uzyskania precyzyjnych danych dotyczących całości wolumenu ruchu turystycznego w Szczecinie ${ }^{3}$.

Struktura narodowościowa turystów odwiedzających Szczecin od wielu lat przedstawia się niezmiennie - najwięcej gości Szczecina pochodzi z Polski i Niemiec; stosunkowo dużo turystów pochodzi z krajów skandynawskich. Turyści pochodzący z innych krajów odwiedzają Szczecin dosyć nielicznie. Czynnikiem odróżniającym jednak dynamikę kształtowania się wolumenu turystów krajowych jest względna stałość wzrostu, podczas gdy na liczbę gości zagranicznych duży wpływ wywierają kursy walutowe - szczególnie wyraźnie widać to $\mathrm{w}$ przypadku turystów z Niemiec, kurs euro do złotego jest zdecydowanie mniej stabilny niż kursy walut skandynawskich. W roku 2009 z noclegu skorzystało 65314 turystów z Niemiec, w 2011 z kolei - 57 957, podczas gdy w 2013 $-65118^{4}$.

Precyzja i wiarygodność badań nad ruchem turystycznym wymaga uwzględnienia wielu czynników, zarówno w skali gminnej, regionalnej, krajowej a nawet międzynarodowej. Skuteczność kampanii marketingowej gmin jest o wiele bardziej skuteczna w przypadku turystów krajowych niż zagranicznych, co jest uwarunkowane faktem, że ci drudzy obierają swoje kierunki podróżowania w dużej mierze w oparciu o aktualne kursy walut - słabość polskiego złotego względem walut obcych jest więc $\mathrm{z}$ punktu widzenia gospodarki turystycznej zjawiskiem korzystnym.

\footnotetext{
${ }^{3}$ Dane ZDiTM Szczecin.

${ }^{4}$ Główny Urząd Statystyczny, 2015 r.
} 


\section{Szczecińskie imprezy turystyczne}

Imprezy masowe organizowane przez samorządy są znakomitym czynnikiem promocyjnym, gdyż nie tylko przyczyniają się do budowania marki miasta, ale przede wszystkim pozwalają zyskać olbrzymie zaplecze promocyjne u osób, które w tych imprezach uczestniczyły. W przypadku dobrej organizacji i gościnności mieszkańców, osoby które odwiedzily teren imprezy, a pochodzą z innych miast bardzo często zachęcają swoich znajomych do odwiedzenia miasta, które zapewniło im rozrywkę na wysokim poziomie. Spośród wielu imprez rozrywkowych, które odbywają się w miastach, zazwyczaj naturalnie obiera się najbardziej efektowną z nich, jako element budowania wizerunku miasta na świecie. Taką imprezą w Szczecinie są zloty żaglowców The Tall Ship's Races, które odbyły się w latach 2007 i 2013, a następnie odbędą się w roku 2017.

Zloty żaglowców stały się mocno rozpoznawalną imprezą masową, a od 2013 roku widać znaczący wzrost liczby turystów odwiedzających Szczecin. (388 082 turystów korzystających z noclegów ogółem w 2014 roku) W sierpniu 2013 r. liczba turystów polskich i zagranicznych korzystających z noclegów wyniosła odpowiednio 26542 i 19 257, podczas gdy w analogicznym okresie roku poprzedniego - 21461 i $15619^{5}$.

O ile pierwszy finał regat The Tall Ship's Races w 2007 roku zachęcił do odwiedzenia Szczecina osoby, które wcześniej tu nie przyjeżdżały, drugi zapewnił utrwalenie wizerunku miasta w świadomości większej liczby turystów. Według szacunków Komendy Wojewódzkiej Policji w Szczecinie, w 2007 r. teren zlotu odwiedziło ok. 2 mln osób, podczas gdy w 2013 - ok 2,25 mln. Mimo panującego w 2013 r. kryzysu gospodarczego turyści wydali w Szczecinie więcej pieniędzy - także z uwzględnieniem inflacji, która w ciągu 6 lat wyniosła ok $23 \%$ - niż w roku 2007. Co więcej, największy wzrost liczby turystów wydających sumy z konkretnych przedziałów dotyczył osób, które wydały podczas zlotu powyżej $500 \mathrm{zl}$ - spośród turystów polskich odsetek ten wzrósł z 4\% do $12 \%$, z kolei wśród turystów zagranicznych $41 \%$ z $11 \%{ }^{6}$.

\footnotetext{
${ }^{5}$ Ibidem

${ }^{6}$ Zarzecki D., Piechota P., Niemczyk R., Lasota J., Przyby lski D., Raport: Wpływ organizacji finału regat The Tall Ship's Races 2013 na gospodarkę Miasta Szczecin, Zarzecki, Lasota i Wspólnicy Sp. z.o.o, Szczecin 2013, s. 18, 33, 40, 44. http://tallships.szczecin.eu/sites/default/ files/ download/tsr_2013_raport.pdf (26.04.2015).
} 
Zlot żaglowców w 2013 został oceniony - zarówno przez mieszkańców, jak również przez turystów - jako znacznie lepiej przygotowany niż edycja z 2007 r. Wynikało to z doświadczeń organizatorów i większego zaangażowania wolontariuszy uczestniczących w obsłudze imprezy, których celem było jak najbardziej gościnne przyjęcie załóg żaglowców i turystów. Podczas obu edycji zlotu, nie doszło w mieście do żadnego większego incydentu o charakterze chuligańskim, a imprezy przebiegały spokojnie, zapewniając uczestnikom zabawę na wysokim poziomie ${ }^{7}$.

Dużym powodzeniem - zarówno wśród turystów jak i mieszkańców - cieszy się coroczny pokaz ogni sztucznych Pyromagic, podczas którego trzy zespoły strzeleckie z różnych krajów prezentują pokazy pirotechniczne. Z roku na rok impreza gromadzi na Wałach Chrobrego coraz więcej osób, wpisując się w markę miasta Szczecin. W odróżnieniu od regat The Tall Ship's Races, Pyromagic nie przyciąga do Szczecina dużych liczb turystów, pomaga jednak w kształtowaniu rozpoznawalności miasta i jest znakomitym narzędziem promocyjnym.

Jednoznacznie kojarzonym ze Szczecinem wydarzeniem stał się coroczny przegląd teatrów małych form Kontrapunkt, który gromadzi coraz więcej gości, głównie z Polski i Niemiec oferując coraz bogatszą ofertę kulturalną ${ }^{8}$.

Poza wymienionymi imprezami, w Szczecinie odbywają się różne inne, często organizowane oddolnie przez hobbystów wydarzenia, które mogą przyczyniać się do wzrostu liczby turystów odwiedzających miasto. Obecnie brakuje jednak możliwości, aby grupy oddolnie organizujące wydarzenia rozrywkowe integrowały się w celu zwiększenia odbioru społecznego organizowanych imprez turystycznych.

\section{Miasta mogące być wzorem dla Szczecina}

Tradycyjnie za najlepszy wzorzec do naśladowania polityki strategicznej uznaje się miasta będące naturalnymi konkurentami - co wynika z licznych podobieństw pomiędzy konkurującymi ze sobą ośrodkami. W przypadku Szczecina, najlepszym przykładem wydaje się być Hamburg, jak również inne miasta w Niemczech położone w basenie Morza Bałtyckiego. O ile możemy porównać znacznie zniszczony w trakcie drugiej wojny światowej Hamburg, będący jed-

\footnotetext{
${ }^{7}$ Ibidem

882 Festiwal Teatralny Kontrapunkt. http://www.kontrapunkt.p1/2015/o_festiwalu.php (16.06.2015).
} 
nym z największych ośrodków portowych w Europie oraz Rostock - który choć znacznie mniej zniszczony od Hamburga posiada znacznie mniejszy potencjał portowy; Szczecin wydaje się być miastem, który ma więcej do zaoferowania turystom z punktu widzenia walorów krajoznawczych niż Hamburg, a jednocześnie stać się portem o znacznie większym potencjale niż Hamburg. Fakt ten powinien stać się wskazówką dla planistów, którzy opracowując długofalową strategię rozwoju turystyki w Szczecinie powinni dążyć do znalezienia złotego środka pomiędzy wykorzystaniem funkcji portowych i historycznych.

Najważniejszym, a zarazem najprostszym elementem polityki turystycznej prowadzonej przez władze Hamburga jest założenie bazujące na tzw. komunikacji trzyfrazowej, polegającej na zwracaniu się do turystów przed podróżą do miasta, w trakcie tej podróży, a także po ich powrocie do domu. To pozwala utrwalić pozytywny wizerunek miasta wśród turystów i zachęcić ich, do polecania wycieczek do Hamburga innym?

Równie ważnym elementem jest dostępność językowa miasta, dzięki któremu otwiera się ono na gości z całego świata oferując im obsługę w ich ojczystym języku - do 2017 r. na Placu Ratuszowym ma powstać pawilon informacyjny w językach wszystkich krajów świata ${ }^{10}$.

Przykład Hamburga pokazuje, jak bardzo skuteczne mogą być przedsięwzięte środki marketingowe. W ciągu 10 lat liczba noclegów ogółem udzielonych w tym mieście wzrosła niemal dwukrotnie; od 5911464 w 2004 r. do 11484453 w 2013 r. ${ }^{11}$.

Z uwagi na bardzo podobny charakter Szczecina i Hamburga, można by podjąć próbę oszacowania wpływu ewentualnego zastosowania hamburskich rozwiązań, na zmianę liczby turystów odwiedzających Szczecin. Przeprowadzając takie szacunki, należałoby jednak pamiętać, iż Hamburg jest znacznie lepiej skomunikowany z resztą Europy, co stawia go w zdecydowanie korzystniejszym położeniu niż Szczecin. Fakt ten dowodzi, że oprócz polityki turystycznej prowadzonej na szczeblu samorządowym, bardzo istotne są działania podejmowane na szczeblu centrahnym, gdyż poprzez budowę odpowiedniej infrastruktury dro-

\footnotetext{
${ }^{9}$ Marketingplan 2010-2015 - Hamburg Tourismus GmbH. http://www.hamburg-tourism.de/ business-presse/wir-ueber-uns/das-unternehmen-hht/marketingplan/ (30.04.2015).

${ }_{10}$ Hamburg will mehr internationale Touristen, Norddeutscher Rundfunk, (13.10.2014) https://www.ndr.de/nachrichten/hamburg/Hamburg-will-mehr-internationale-Touristen,tourismus 428.html (01.05.2015).

${ }^{11}$ Federalny Urząd Staty sty czny, 2015 r.
} 
gowej, kolejowej, wodnej i lotniczej Szczecin stałby się celem znacznie łatwiejszym dla turystów.

Drugim przykładem miasta mogącego stanowić znakomity wzór dla Szczecina jest Lubeka, która jako dawna stolica Hanzy wypracowała bardzo zbliżone dziedzictwo historyczne. Chociaż miasto to odwiedza znacznie mniej turystów niż Hamburg, to jednak współczynnik liczby gości w stosunku do liczby mieszkańców w 2013 r. osiągnął większą wartość - 6,52 w Lubece wobec 6,38 w Hamburgu. W 2013 r. Lubekę odwiedziło 1373802 gości, podczas gdy w 2004 r. $-931679^{12}$.

Władze Lubeki skupiają się na tradycyjnych formach prowadzenia kampanii marketingowych - głównie poprzez uczestnictwo w targach międzynarodowych - ale również poprzez wykorzystywanie w promocji walorów turystycznych miast ościennych - jest to zatem wskazówka dla władz Szczecina, które mogłyby połączyć w polityce promocyjnej walory historyczne Szczecina z potencjałem Międzyzdrojów i Świnoujścia ${ }^{13}$.

\section{Charakterystyka bazy Hotelowej i Gastronomicznej w Szczecinie}

Bezpośrednim skutkiem wzrostu liczby turystów są inwestycje w branży hotelowej i gastronomicznej. W ostatnich kilku latach przybyło w Szczecinie kilka hoteli o różnych standardach, jednak największy przyrost liczby miejsc hotelowych ma nastąpić w latach nadchodzących. Popyt na usługi turystyczne w Szczecinie rośnie, a planowane, bądź oddawane do użytku nowe obiekty hotelowe i gastronomiczne różnią się między sobą standardem i cenami.

Obecnie jedyną spośród znanych na całym świecie marek hoteli, która posiada swój obiekt w Szczecinie jest Radisson Blue. Jedną z najważniejszych inwestycji hotelowych $\mathrm{w}$ Szczecinie nadchodzących lat jest $\mathrm{z}$ kolei planowany zespół hotelowo-konferencyjny w sąsiedztwie Bramy Portowej, który ma zbudować spółka-córka należąca do szczecińskiego przedsiębiorstwa budowlanego Calbud. Kompleks ma składać się z odnowionego budynku po dawnej galerii Centrum - zwanego potocznie przez szczecinian „Posejdonem” lub „Pedetem”

\footnotetext{
${ }^{12}$ Ibidem

${ }^{13}$ Tourismus Marketing, Lübeck Travemünde marketing, www.luebeck-marketing.de/ ueberuns/taetigkeitsbereiche/tourismusmarketing.html (02.05.2015).
} 
oraz nowych zabudowań, gdzie swoją siedzibę znajdzie sieć prestiżowych hoteli Marriott. Oddanie do użytku całego kompleksu planowane jest na 2019 rok $^{14}$.

Kolejną bardzo ważną i prestiżową inwestycją hotelową w Szczecinie jest gruntowna modernizacja XIX-sto wiecznej kamienicy u wlotu ulicy Potulickiej w Plac Zwycięstwa, gdzie powstać ma hotel marki Hilton ${ }^{15}$. Równie ważną inwestycją jest budowa małego hotelu nad jeziorem Rusałka - obiekt ten ma nawiązywać architektonicznie do przedwojennej restauracji Haus am Westendsee, która rozebrana została $\mathrm{w}$ latach $60 . \mathrm{XX}$ wieku ${ }^{16}$. Jedną $\mathrm{z}$ ważniejszych, już ukończonych inwestycji jest czterogwiazdkowy hotel Dana, zlokalizowany W wyremontowanej siedzibie dawnej szwalni ${ }^{17}$.

Oszacowanie wartości współczynników określających wzrost liczby obiektów gastronomicznych jest metodycznie zdecydowanie trudniejsze niż hoteli, zarówno istniejące, jak również nowopowstające obiekty gastronomiczne różnią się między sobą wielkością i wachlarzem oferowanych usług. Trudno jednoznacznie określić metodykę badań takich obiektów, bowiem ich ocena w dużej mierze zależy od gustów i opinii ich klientów, które mogą być przedmiotem swobodnego zbioru informacji a nie badań naukowych. Trudno również ocenić faktyczny przyrost liczby miejsc gastronomicznych, chociażby z uwagi na fakt, że często zachodzące zmiany włácicieli obiektów skutkują zwiększeniem zmianą liczby oferowanych miejsc w ramach tego samego lokalu, trudności nastręcza więc sporządzanie odpowiedniej ewidencji, na podstawie której można by szacować stosunek liczby miejsc do wielkości i ilości lokali.

\section{Podsumowanie}

Wzrost ruchu turystycznego $\mathrm{w}$ ostatnich latach jest wynikiem zarówno działań podejmowanych na różnych szczeblach, jak również ogólnoświatowych procesów gospodarczych. Bardzo skutecznym środkiem promocyjnym Szczeci-

\footnotetext{
${ }^{14}$ Mag, Podwójny Marriott , Kurier Szczeciński, 28.07.2016 r. http ://www.24kurier.pl/ aktualnosci/wiadomosci/podwojny-marriott/ (11.08.2016).

${ }^{15}$ (brak inf. o aut.). rozpoczęła się budowa Hiltona w Szczecinie, Hotelarz, 15.04.2016 r.

http://www.e-hotelarz.pl/mht/?p=36665

${ }^{16}$ Trm, Tak będzie wy glądać hotel Rusałka w Parku Kasprowicza, jak Wam się podoba, Gazeta Wyborcza Szczecin, 07.02.2015. http://szczecin.wyborcza.pl/szczecin/56,34939,17373773, Tak_bedzie_wygladac_Grand_Park_Rusalka_w_parku_Kasprowicza_html (11.08.2016).

17 Jasina P., Hotel Dana przyjmuje już gości. Dziś oficjalne otwarcie, Głos Szczeciński, 27.11.2015 http://www.gs24.p1/wiadomosci/szczecin/art/9128332, hotel-dana-przyjmuje-juz-goscidzis-oficjalne-otwarcie-zdjecia,id,t.html (11.08.2016).
} 
na są liczne imprezy masowe, które wpisują się coraz bardziej w markę miasta. Problemem jest brak długofalowej i szerokiej kampanii promocyjnej, jak również rozpoznawalnego $\mathrm{w}$ wielu krajach lokalnego produktu turystycznego. $\mathrm{O}$ ile ta pierwsza mogłaby być wzorowana na innych miastach, o tyle wypracowanie lokalnego produktu turystycznego jest zadaniem nie łatwym i wymaga współpracy pomiędzy środowiskami hobbystów i fachowców. Szczecin posiada szerokie zaplecze kadrowe, które mogłoby podjąć się zarówno wypracowania lokalnej odmiany polityki innego miasta, jak również współgrających z nią integrahie produktów turystycznych.

Większy popyt na usługi turystyczne przyczynia się do powstawania nowych miejsc pracy w tym sektorze, to z kolei powoduje większą konsumpcję co jest kolejnym, już ściśle ekonomicznym pozytywnym zjawiskiem. Koszty prowadzenia szeroko rozumianych działań promocyjnych są w stosunku do potencjalnych zysków bardzo niskie. Przyrost liczby turystów odwiedzających miasta jest czynnikiem, który przyczynia się do powstania ciągu zdarzeń gospodarczych przyczyniających się do ogólnie rozumianego rozwoju gospodarczego i społecznego miasta. Skutkuje on również zwiększeniem rozpoznawalności miasta wśród przedsiębiorców i korporacji, które chętniej lokują swoje interesy właśnie tutaj.

\section{Bibliografia}

Rozpoczęta się budowa Hiltona w Szczecinie, Hotelarz, 15.04.2016. http://www.ehotelarz.p1/mht $/ \mathrm{p}=36665$

Festiwal Teatralny Kontrapunkt http://www.kontrapunkt.p1/2015/o_festiwalu.php (dostęp 16.06.2015).

Dane ZDiTM Szczecin

Federalny Urzad Statystyczny.

Gtówny Urząd Statystyczny, 2015 r.

Hamburg will mehr internationale Touristen, Norddeutscher Rundfunk, 13.10.2014 https://www.ndr.de/nachrichten/hamburg/Hamburg-will-mehr-internationaleTouristen,tourismus428.html (dostęp 01.05.2015).

Jasina P., Hotel Dana przyjmuje już gości. Dziś oficjalne otwarcie, Głos Szczeciński, 27.11.2015. http:/www.gs24.p1/wiadomosci/szczecin/art/9128332,hotel-danaprzyjmuje-juz-gosci-dzis-oficjalne-otwarc ie-zd jecia,id,t.html (dostęp 11.08.2016).

Mag, Podwójny Marriott, Kurier Szczeciński, 28.07.2016 http://www.24kurier.pl/ aktualnosci/wiadomosci/podwojny-marriott/ (dostęp 11.08.2016).

Marketingplan 2010-2015 - Hamburg Tourismus GmbH http:/www.hamburgtourism.de/bus ines s-presse/wir-ueber-uns/das-unternehmen-hht/marketingplan/ (dostęp 30.04.2015). 
Tourismus Marketing, Lübeck Travemünde marketing, www.luebeck-marketing.de/ ueber-uns/taetigkeits bereiche/tourismusmarketing.html (dostęp 02.05.2015).

Trm, Tak będzie wyglądać hotel Rusałka w Parku Kasprowicza , jak Wam się podoba, Gazeta Wyborcza Szczecin, 07.02.2015. http://szczecin.wyborcza.pl/szczecin/ 56,34939,17373773,Tak_bedzie_wygladac_Grand_Park_Rusalka_w_parku_Kaspr owicza_html (dostęp 11.08.2016).

Zarzecki D., Piechota P., Niemczyk R., Lasota J., Przybylski D., Raport: Wpływ organizacji finatu regat The Tall Ship's Races 2013 na gospodarke Miasta Szczecin, Zarzecki, Lasota i Wspólnicy Sp. z.o.o, Szczecin 2013, s. 18, 33, 40, 44 http://tallships.szczecin.eu/sites/default/files/download/tsr_2013_raport.pdf(dostęp 26.04.2015).

\section{Rating of tourist flows in Szczecin - barriers of development}

\section{Summary}

This article describes tourist flows in city of Szczecin between 2009 and 2014 year, and influence of marketing policy of city municipal of Szczecin for number of tourists who visit city. Article contains a comparation of marketing policy of another cities, and present possibilities, how to adapt and implement this solutions in Szczecin. In this art icle has been described influence of big events on touristic flows. In article have been places diagrams, that presents number of tourist who visited Szczecin, and cost of promotional actions. Data in this article com first of all from polish Centre Statistical Office, German Statistisches Bundesamt, and many others articles concerned with events and politics in Szczecin. 